\title{
John Webster on the task of a properly theological theologia
}

\author{
Tyler Wittman* \\ Southern Baptist Theological Seminary, Louisville, KY 40206 \\ ${ }^{*}$ Corresponding author. Email: twittman@sbts.edu
}

\begin{abstract}
The late John Webster advocated both for a theological theology and a robust recovery of God's intrinsic perfection. This article examines how both occupations are related in Webster's thought by setting forth six statements summarising his doctrine of God and his theological approach to it. According to Webster, the doctrine of God is theological to the extent it upholds the principle of solus Deus in theology's formal and material consideration of God's perfection. Only thus does theology articulate the crucial distinction between and yet correspondence of God's antecedent perfection and God's intimate presence with us.
\end{abstract}

Keywords: divine attributes; God; perfection; Trinity; John B. Webster

The late John Webster's work is marked from beginning to end by his steady advocacy for 'theological theology', which draws several of his other occupations in its wake. Christian thought on such matters as the place and significance of tradition, theological anthropology or the doctrine of scripture is considered theological just to the extent that reference to God's being and activity is necessary and not merely incidental. For example, when Webster first treats theology's theological character, he points out that theology's distinctiveness is in its invocation of God as agent in the intellectual practice of theology'. ${ }^{1}$ Revisiting this theme towards the end of his career, he fills out the significance of 'theological' by depicting theology's object, cognitive principles, ends and the requisite virtues of theologians. Here God's perfection and presence gives these various criteria form and content: theology is chiefly about God and all else in relation to God, and so it apprehends God as the missions of the Son and Spirit create 'creaturely form and extension' in regenerate human intelligence. ${ }^{2}$ How 'theological' functions is therefore suspended between God's being and activity on the one hand and the appropriate dispositions with which theology attends to this object on the other. The intuition has a long pedigree, but Webster often unfolds it in the course of showing how little work it actually does for some dominant strands of modern theology - including modern

\footnotetext{
${ }^{1}$ John Webster, 'Theological Theology', in Confessing God: Essays in Christian Dogmatics II (London: Bloomsbury T\&T Clark, 2016), p. 25.

${ }^{2}$ John Webster, 'What Makes Theology Theological?', in God without Measure: Working Papers in Christian Theology (hereafter GWM), 2 vols (London: Bloomsbury T\&T Clark, 2016), vol. 1, p. 217.

(C) Cambridge University Press 2020
} 
thought on the doctrine of God itself. At the end of an essay on trinitarian dogmatics, Webster registers his overarching concern: 'Amongst the more important tasks of Christian dogmatics in the present is the articulation of an evangelically-determined theology of God's perfection. There are more options than either materially-unspecific perfect being theology, or neo-Hegelian presentations of God's career in time., ${ }^{3}$ One captures here something of Webster's misgivings about modern doctrines of God, but what about his own attempt to fulfil this task? What, in other words, makes theology proper properly theological? The question seems to heighten the tautology of 'theological theology' to the breaking point, but precisely here we may stumble upon some essential insights into what a theological doctrine of God might look like.

Posing this question to Webster's work affords insight on some central threads of his thought, but also on what he considered some typical pitfalls and possible solutions to vexing questions surrounding divine perfection. For our present purposes, God's 'perfection' encompasses not only what theologians might say about God's nature and intrinsic life but also the form of its extension towards creatures. Few matters in theology are more disputed than the serviceability or meaning of 'perfection' in this regard. Ready examples may be found in philosophical deliberations about perfect being, or reconsiderations of divine perfection through the straights of a 'historicized semantics' of biblical and creedal texts, ${ }^{4}$ 'fall' narratives about the corrupting influence of Greek metaphysics and so forth. Webster has deep reservations about such approaches and their assumptions on a range of matters, but especially the nature of reason and scripture. And while his own thought on the matter has strong affinities with Protestant scholasticism, it is not a slavish reproduction. This essay outlines Webster's views on divine perfection, situated within his particular construal of the nature of theology as well as the habits of mind most conducive to the task. According to Webster, the doctrine of God is theological to the extent it upholds the principle of solus Deus in theology's formal and material consideration of God's perfection. Only thus do we secure both God's antecedent perfection in himself and his intimate presence with us. The discussion proceeds by elaborating a series of six summary statements that take their cues from Webster's thought, but which also attempt to fill in some of the gaps and so risk saying more than he says. These statements are divided into two groups of three, addressing the formal and material considerations of a theological theology proper, respectively.

\section{Approaching God's perfection theologically}

A full account of Webster's doctrine of God would need to account for his theology of scripture, the modes of reasoning proper to theology and the nature of theology more generally. Our first three summary statements touch on these matters representatively, but not exhaustively. Together, they show how a theological doctrine of God is embedded in a culture conducive to the right kind of inquiry, namely, one that upholds the notion of solus Deus substantively in its rational operations.

\footnotetext{
${ }^{3}$ John Webster, 'Eternal Generation', in GWM, vol. 1, p. 41.

${ }^{4}$ See Christine Helmer, 'Between History and Speculation: Christian Trinitarian Thinking After the Reformation', in Peter C. Phan (ed.), The Cambridge Companion to the Trinity (Cambridge: Cambridge University Press, 2011), pp. 149-69.
} 
First, 'God is the formal object of each Christian doctrine', even the doctrine of God. ${ }^{5}$ As such, theology is 'a distinct and unified science' that finds its centre in God himself. ${ }^{6}$ In a manner that is circular without being viciously so, the Christian doctrine of God must be set forth sub ratione Dei. This does not mean that theology presumes to develop a doctrine of God from God's perspective. Rather, it means a particular conception of theology's object and ends shaped by 'the great trinitarian principle of all dogmatics and ethics: solus Deus'.

\section{1}

Following Aquinas, Webster holds that theology's object is 'God and all things in relation to God'. Unpacking this definition with reference to God as the formal object discloses the preliminary significance of a theological doctrine of God. That is to say, we need to understand each of the three parts of this definition - 'God', 'and', 'all things' from the light shed upon them when they are considered 'in relation to God'. We best grasp Webster's perspective here by considering these elements in reverse.

At the end of its responsibilities, theology considers 'all things' in relation to God. 'All things' refers to the whole economy of creation and redemption, embracing any and all things theology may consider under the umbrella of creation. Theology finds itself able to say what it may about anything and everything only by studious reference of all things to God their creator, sustainer, and perfecter. So by considering 'all things relative to God', we should understand that theology encompasses everything to the extent that it is focused on God's ways. As such theology is a science about everything, but not 'everything about everything. 8

Standing materially prior to these responsibilities, theology understands the word 'and' itself in relation to God: the conjunction signals a dogmatic locus connecting the subjects 'God' and 'God's effects' without confusing them. Here theology discusses God's 'transitive works in relation to their source in the goodness and wisdom of the divine nature and counsels, and then considers their outer enactment in the divine works of nature and grace'. 9 In other words, 'and' signals the necessity of discussing carefully the sequence of topics related to God's inner and outer activity, which is typically discussed with reference to the decree (or the foreordering of all things, providentia).

At the head of all these considerations, theology treats 'God' in relation to God. This results in a study of God 'absolutely, that is, God in himself in his antecedent selfexistent perfection, integrity, beatitude and simplicity as Father, Son and Spirit, prior to and apart from any relation to creatures' ${ }^{10}$ God's absolute life is the chief and formal consideration of all theology and religion - chief, we should take care to note, not lone.

\footnotetext{
${ }^{5}$ John Webster, 'Christology, Theology, Economy: The Place of Christology in Systematic Theology', in $G M W$, vol. 1, p. 57.

${ }^{6}$ John Webster, 'Omnia ... pertractantur in sacra doctrina sub ratione Dei: On the Matter of Christian Theology', in GWM, vol. 1, p. 4.

${ }^{7}$ John Webster, 'Christ, Church and Reconciliation', in Word and Church: Essays in Christian Dogmatics (Edinburgh: T\&T Clark, 2001), p. 227.

${ }^{8}$ Webster, 'What Makes Theology Theological?', p. 215.

${ }^{9}$ Ibid., p. 214.

${ }^{10}$ Ibid., p. 213.
} 
Only as theology considers God in relation to God does it see clearly the 'and' and 'all things' that constitute the remainder of its object.

\section{2}

If theology's ultimate consideration of God is in relation to himself, then one of theology's ends is contemplative. Intellectual activity becomes theological as it 'tends' towards the 'contemplation of the infinite excellence of the divine being. ${ }^{11}$ Webster here gives voice to the doctrine of the beatific vision, and this affects how theology shapes its inquiry and adjudicates its questions in the present. Spiritual perception of God's glory is the fulfilment of reason: 'To know God's perfection properly, creatures must themselves be perfected, brought to their proper end'. ${ }^{12}$ Contemplation is understood in a minimal sense, without the baggage of much mystical experience attached to it. All Webster seems to mean by the concept is that the Holy Spirit leads the intellect through created signs to their res in God's inner life, leading from what is real to that which is most real: 'Theology is rapt attention to God the cause of all things rather than to the things of which he is the cause. ${ }^{13}$ One consequence of this contemplative approach is that theology will be concerned to draw several distinctions, foremost among which is that between theology and economy. The reason why: revelation's 'historical form' has an 'unforgettable density but also a finality, and therefore an instrumental character'. ${ }^{14}$ In the first place, then, the doctrine of God is theological if solus Deus shapes its object and ends.

\section{2}

Second, theological reflection on the doctrine of God occurs in the wake of God's objective self-presentation in the economy of his works, and so it is answerable to God. That is to say, the theological approach to God shaped by solus Deus is constrained as a form of following after an object that infinitely precedes and outpaces it. Theology is 'acknowledgement of a mobile, self-bestowing personal presence'. ${ }^{15}$ Teaching about God must be a form of confession ordered to worship. Couched within this objective orientation are proscriptions and prohibitions, which we may expand in turn.

\section{1}

Positively, God's objective pre-eminence means that theology is a responsive rather than spontaneous science. Theology responds to God's indirect self-revelation through various media, and direct revelation through his activity 'normatively rehearsed in the biblical writings'. ${ }^{16}$ Created reality bears some indirect testimony to God that is 'anticipated and enabled by revelation', and so contemplation of created signs will never be a 'work of purely natural reason'. Therefore, God's perfections are not attributed to, but

\footnotetext{
${ }^{11}$ Ibid., p. 214.

${ }^{12}$ John Webster, 'God's Perfect Life', in Miroslav Volf and Michael Welker (eds), God's Life in Trinity (Minneapolis, MN: Fortress Press, 2006), p. 152.

${ }^{13}$ Ibid., p. 220.

${ }^{14}$ Webster, 'On the Matter of Christian Theology', p. 6.

${ }^{15}$ John Webster, 'The Divine Attributes', in Ian A. McFarland, David A.S. Fergusson, Karen Kilby and Ian R. Torrance (eds), The Cambridge Dictionary of Christian Theology (Cambridge: Cambridge University Press, 2011), p. 47.

${ }^{16}$ Ibid., p. 46.
} 
'confessed' of God. ${ }^{17}$ Theology's realist and objective commitments derive from the object of God's self-revelation, and not an independent philosophy of being or existence.

\section{2}

The object theology pursues at this point also renders certain forms of inquiry unsuitable. Theology is exhibitive rather than demonstrative (theologia non est habitus demonstrativus, sed exhibitivus) because it has its origin and occasion in the positum of divine instruction, and not in cultural hermeneutics, natural divinity or projects of cosmological explanation. ${ }^{18}$ Therefore, theology cannot satisfy itself with idealist inquiry into abstract models of divine perfection that adjudicate what perfection is prior to or apart from indicating its objective enactment. The theme of God's perfection in particular is a keenly sensitive register of the divergences between some kinds of philosophical and theological inquiry, over such matters as the sources of teaching about God, the relation of non-biblical concepts to scripture, the ways in which classical Christian texts are most fittingly read, and the ends of an intellectual conception of God'. ${ }^{19}$ Invocation of God in prayer, ascesis, and the reading of scripture in the company of the saints is elevated over the demonstration of generic ideals of perfection. Webster's concern with procedures like 'perfect being theology' is that they often proceed by materially unspecific comparative description: whatever God is, we must first satisfy conditions for the intelligibility of deitas through appeal to great-making properties. But since theology concerns itself with confession, then it does not proceed through the construction of models 'synthesized from observations on creaturely realities' ${ }^{20}$ Hence, the task of the doctrine of God 'is not to establish conditions for conceivability but rather to have rational dealings with the God who is, and is self-communicative, anterior to rational work on our part'. ${ }^{21}$

\section{3}

Since the science of God is determined by its object's self-presentation, then much depends on the form of this disclosure. The God whom theology encounters is YHWH, the holy Trinity who is known in the Lord Jesus Christ as 'infinite personal subject and agent'. ${ }^{22}$ Here we encounter one of Webster's key convictions. The form of God's self-expressive being is one in which God is the sovereign Lord, and the

\footnotetext{
${ }^{17}$ Ibid. For further reflection on the distinction between attribution and confession, see Janet Martin Soskice, 'Naming God: A Study in Faith and Reason', in Paul J. Griffiths and Reinhard Hütter (eds), Reason and the Reasons of Faith (New York: T\&T Clark, 2005), pp. 241-54.

${ }^{18}$ See here John Webster, 'The Dogmatic Location of the Canon', in Word and Church, p. 11; Holiness (Grand Rapids, MI: William B. Eerdmans, 2003), pp. 16, 37; 'The Holiness and Love of God', in Confessing God, p. 110; 'Divine Attributes', p. 46; 'Life in and of Himself, in GWM, vol. 1, pp. 13-18. Much the same concern about the positum of God's self-communicating presence animated Webster's interest in Barth's moral theology as a necessary supplement to emphases on tradition in communitarian ethics: Barth's Ethics of Reconciliation (Cambridge: Cambridge University Press, 1995), pp. 222-3. This is part of Webster's unease with 'post-liberalism': 'Locality and Catholicity: Reflections on Theology and the Church', Scottish Journal of Theology 45/1 (1992), pp. 1-17.

${ }^{19}$ John Webster, 'Divine Aseity', in Michael Scott and Andrew Moore (eds), Realism and Religion: Philosophical and Theological Perspectives (Aldershot: Ashgate, 2007), p. 147.

${ }^{20}$ Webster, 'God's Perfect Life', p. 144.

${ }^{21}$ Webster, 'Life in and of Himself, p. 13.

${ }^{22}$ Webster, 'The Divine Attributes', p. 46.
} 
self-moved relations God bears towards us in time reveal his freedom, which in turn is grounded in the internal relations of the Trinity. How God relates to us thereby beckons our attentions to his inner life, which is the 'formal reason, foundation, and object of all religion'. ${ }^{23}$ Moved by the missions of the Son and Spirit to their processions, our intellect and affections respond to God's self-revelation by distinguishing between God's perfection (theology) and his presence (economy). Thus solus Deus shapes the substantive movements of the mind as it follows the particular fellowship God establishes and maintains with us in the covenant. ${ }^{24}$ In order to do this, theology makes use of concepts suited to depicting this reality.

\section{3}

Third, distinguishing God's inner perfection and his presence with creatures requires theology to use concepts whose adequacy is a matter of their descriptive capacity and material density. Intrinsic to the history of theology's appropriation of metaphysical tools is the analysis, redefinition and deployment of particular concepts, like 'substance' or 'relation'. The serviceability of concepts depends largely on how transparent they are to the biblical text, not semantically as much as substantively. Unpacking what Webster means by these criteria will take us further into the specifics of his doctrine of God and conclude our overview of the procedures proper to it.

\section{1}

The proper function of concepts is part of Webster's attention to the kinds of rhetoric most fitting to the peculiar domain and culture theology inhabits, and in which alone it thrives. Hallmarks of this rhetoric are 'modesty and transparency', meaning that theology operates best through dispositions of effacement. ${ }^{25}$ Part of what is at issue here is the modesty of conceptual analysis itself, which, while necessary and important, is neither intrinsically illuminating nor risk-free. Excesses must be avoided, like the temptation to imbue conceptual analysis with revelatory immediacy: our words are only attestations, not the thing itself. Theology has to be 'properly mistrustful of its own command of its subject-matter; modest; aware that much of what it says and thinks is dust'. ${ }^{26}$ Our concepts are constantly open to revision, not necessarily by more sophisticated philosophical systems, but by the Spirit's mortification and vivification of theological reason as it submits to divine instruction in Holy Scripture. Aware of these limitations and our sinfulness, the real heart of the matter concerns our effacement before divine teaching. Yet again 'the logic of theological attribution is not ascription but acknowledgement'; it is resolutely a matter of confession, 'a recognition of and a decision for divine teaching, ${ }^{27}$ Conceptual articulation is therefore an element in biblical reasoning insofar as concepts represent the matter of scripture itself in its 'unity

\footnotetext{
${ }^{23}$ John Owen, Christologia, in The Works of John Owen, ed. William H. Goold, vol. 1 (Edinburgh: Banner of Truth Trust, 1965), p. 44; cf. Webster, 'What Makes Theology Theological?', p. 213, n. 1.

${ }^{24}$ For a worked-out example of this, see John Webster, 'Perfection and Participation', in Thomas Joseph White (ed.), The Analogy of Being: Invention of the Antichrist or the Wisdom of God? (Grand Rapids, MI: William B. Eerdmans, 2011), pp. 389-94.

${ }^{25}$ John Webster, 'Texts: Scripture, Reading, and the Rhetoric of Theology', Stimulus 6/4 (1998), p. 15.

${ }^{26}$ Webster, Holiness, p. 28.

${ }^{27}$ John Webster, 'On the Clarity of Holy Scripture', in Confessing God, p. 38.
} 
and scope'. ${ }^{28}$ If the cogency of concepts is in large measure a question of how well they 'display systematic relations between different aspects of Christian teaching', then 'it may be better to make greater use of concepts that are less formal and more material'. ${ }^{29}$

\section{2}

Descriptively rich concepts curb the temptation to privilege other sources of theological understanding than God's own self-utterance, and to consider ourselves competent to construct an adequate understanding of God on some other basis. Hence, the more materially precise the concept and less open to analytic abuse, the more descriptively adequate it is. Webster's own preference for certain concepts evolves and tells us much about what he considers descriptively adequate.

In one of his first direct forays into the doctrine of God's perfection, he uses the concept of causa sui to signify God's aseity, and elaborates with Isaak Dorner's concepts of God's 'self-preservation' (Selbstbehauptung) and 'self-communication' (Selbstmittheilung). ${ }^{30}$ Dorner's concepts are preferred because 'more precise, and so correspondingly less likely to attract the wrong kind of expectations or to be filled out with improper content' than Karl Barth's 'more general terms such as freedom and love'. ${ }^{31}$ However, the delimitations Webster has to give the concept of Selbstbehauptung in particular do not fully convince: 'Divine self-preservation is not to be conceived as a countermove, a defense of God's perfection against that which might corrupt it or break it down. ${ }^{32}$ As a concept anterior to and undergirding notions like divine peace and beatitude, divine self-preservation invites misinterpretations along the lines of 'preservation from', which sits awkwardly alongside God's simplicity. Perhaps for some such reason, then, in a mature essay on divine aseity that repeats much of the earlier essay's content, Webster leaves Dorner's concepts behind along with the notion of causa sui. Now he prefers simply to discuss relations of origin as materially transparent to the perfect movement of God's life in and from himself. The concept of causa sui falters because it suggests that God 'produces himself, and 'seems to require the possibility of God's non-existence as a kind of background to being'. Much the same might be said about disintegration as the background to 'self-preservation', though Webster does not voice any such concern. Whether the notion is causa sui, the Absolute, or even ens necessarium, the more formal the notion is the more it invites filling out from elsewhere' and thus 'has to be judged materially inadequate as an account of God's life'. 33

\footnotetext{
${ }^{28}$ John Webster, 'Principles of Systematic Theology', in Domain of the Word: Scripture and Theological Reason (hereafter DW) (London: T\&T Clark International, 2012), p. 144. Elsewhere, he says, 'the prophetic and apostolic sermo remains the governor of theological discourse, not simply that which we pass through on the way to the res' ('Biblical Reasoning', in $D W$, p. 131, n. 34). A fundamental corollary here is that dogmatics 'cannot resolve scriptural mediacy into revelatory immediacy' ('The Domain of the Word', in $D W$, p. 9).

${ }^{29}$ Webster, 'God's Perfect Life', p. 146.

${ }^{30}$ Ibid., pp. 143, 146; cf. Dorner, A System of Christian Doctrine (Edinburgh: T\&T Clark, 1880), vol. 1, p. 454.

${ }^{31}$ Webster, 'God's Perfect Life', p. 146.

${ }^{32}$ Ibid., p. 147.

${ }^{33}$ Webster, 'Life in and of Himself, p. 23. Compare Webster's discussion of ens necessarium with Eberhard Jüngel, God as the Mystery of the World: On the Foundation of the Theology of the Crucified One in the Dispute Between Theism and Atheism, trans. Darrell Guder (London: Bloomsbury, 2014), pp. 14-35. Webster is more sanguine about God's necessitas absoluta, and so feels no compulsion towards Jüngel's account of necessity.
} 
Materially adequate concepts therefore ensure 'that conceptual articulation of the faith echoes the scriptural economy of revelation in the evangelists'. ${ }^{34}$ It is in this way that scripture is the terminus a quo and terminus ad quem of theology's analytical idiom. ${ }^{35}$ For example, notions like aseity and inseity display the comprehensive scope of teaching about God's life in the christology of John's Gospel: 'the Son gives life to whom he will' (John 5:21); and the reason why is because 'as the Father has life in himself, so he has granted the Son also to have life in himself (John 5:26). We know this because 'from his fullness we have all received, grace upon grace' (John 1:16). Especially since the evangelist teaches us that the form of God's 'life-giving overflow ... is the Son', then we are beckoned to consider further the ground of this overflow in the Son's relation to the Father and its enactment in the Son's sending from the Father in time. ${ }^{36}$ If the history of Jesus 'is indeed the presence of God and the gift of divine life', then we must reflect on what such a confession presupposes about the identity of the Son in relation to the Father. ${ }^{37}$ Concepts like eternal generation and eternal spiration thus serve as materially adequate concepts because they disclose the personal identities of the Father, Son and Spirit which are echoed but not constituted in the economy. ${ }^{38}$

\section{Material considerations of God's perfection}

So far we have considered three elements of Webster's formal approach to the doctrine of God, as it concerns the elucidation of God's perfection and his presence. Now we turn in three further representative statements to some material claims about God's perfection, which we have already stumbled upon. Webster maintains that an evangelically regulated theology of God's perfection is one that secures the distinction between theology and economy while simultaneously doing justice to God's fellowship with creatures, one which is determined by his intrinsic perfection and so adds nothing to God.

\section{4}

The distinction between theology and economy is procured by a series of further conceptual distinctions between uncreated and created, absolute and relative, procession and mission, internal activity and external acts. These distinctions are not arbitrary but pressed upon us in light of what scripture says about God's life and such acts as election and creation ex nihilo. The relations spelled out by these various distinctions are asymmetrical, irreversible and non-reciprocal. For but two examples, we may consider the distinctions between uncreated and created, and procession and mission.

\section{1}

The distinction between uncreated and created is basic to the doctrine of creation. As the creator of all things ex nihilo, God is uncreated and therefore qualitatively distinct

\footnotetext{
${ }^{34}$ Webster, 'Eternal Generation', p. 32.

${ }^{35}$ Webster, 'Principles of Systematic Theology', p. 148.

${ }^{36}$ Webster, 'Life in and of Himself, p. 26.

${ }^{37}$ Webster, 'Eternal Generation', p. 29. Expressing what scripture depicts requires the use of a variety of concepts, which is why in christology 'historical' concepts like 'turning' and 'movement' are as instructive as concepts like substance, nature or person: 'Prolegomena to Christology: Four Theses', in Confessing God, p. 149; 'Incarnation', in Word and Church, pp. 143-8.

${ }^{38}$ Webster, 'Eternal Generation', pp. $30-1$.
} 
from all things. Whereas creatures move towards their perfection as they enact their natures, God is simply perfect and has no distinction between his being and his act, or his essence and existence. God is thus actus purus; his being is his act, though we must be careful what we mean by this phrase. For much modern divinity, Webster observes, 'God's being is act, and God's act [is] principally understood as external (or externally manifest) operation; in terms of its terminus ad quem'. ${ }^{39}$ Such understandings prioritise economy over theology, tend towards a kind of christological maximalism and obscure how God's external works are grounded in his perfect inner life. On the contrary, 'God's being is indeed in act; but by "act" here we do not restrict ourselves to those acts whereby God establishes, preserves, redeems and perfects creatures, but also primarily - refer to the infinite underivative movement of God in himself, which is the founding condition of the economy. ${ }^{40}$ Therefore, to say that God's essence is identical with his existence is to say God is ipsum esse subsistens, not that God's simplicity makes historical relation somehow irreducible. ${ }^{41}$ The Creator is the principle of all things but does not have a principle of his own being; God is therefore transcendent, not simply in his identity and thus de facto but 'transcendent in nature' and thus de jure. ${ }^{42}$ Such metaphysical statements are ministerial, and according to Webster they arise from God's enacted identity as witnessed to in the covenantal history established by his electing will in Jesus Christ.

\section{2}

Closely related to the distinction between uncreated and created is that between the eternal processions and temporal missions of the Son and Spirit. The history of God's enacted identity is suspended from God's immanent life. To the extent that conceptual reflection on God's perfection does not lose sight of the utter distinction between uncreated and created, with all of that distinction's entailments, it also distinguishes between mission and procession. Missions echo processions, and processions ground missions. But theological reflection on these processions is given the greatest material density when it involves a steady contemplation on the personal properties

\footnotetext{
${ }^{39}$ Webster, 'Christology, Theology, Economy', p. 53. On the characteristics of creatures generally, see 'The Dignity of Creatures', in GWM, vol. 2, p. 35.

${ }^{40}$ John Webster, 'Trinity and Creation', in GWM, vol. 1, p. 86. 'Paternity, filiation and spiration are the life-filled abundance of God's being, his pure act in which he is who he is' ('It was the Will of the Lord to Bruise Him": Soteriology and the Doctrine of God', in GWM, vol. 1, p. 152).

${ }^{41}$ Webster, 'Trinity and Creation', p. 86; 'Life in and of Himself, p. 23. Webster's definition of actus purus in terms of esse subsistens marks something of a move away from some of his first forays into the doctrine of God, in which he seems to have accorded such weight to 'historical relation': Holiness, p. $109, \mathrm{n}$. 25. It also reflects a change in how he understands the doctrine of divine simplicity. Early on, he follows Barth's account of simplicity as it comes to him through Jüngel: Holiness, pp. 34, 39; Jüngel, 'Theses on the Relation of the Existence, Essence and Attributes of God', Toronto Journal of Theology 17/1 (2001), pp. 55-74. For instance, he speaks of God's simplicity as 'his irreducible "thisness", executed in the drama of his works' (Holiness, p. 38; Barth's Ethics of Reconciliation, pp. 40-4; cf. also the comments on 'particularity' in 'Incarnation', pp. 131-2). That Webster stops straightforwardly speaking of simplicity in this manner perhaps suggests some unease with how Jüngel prioritised God's existence to determine the content and supplant the absoluteness of God's essence. On Jüngel, see Paul J. DeHart, Beyond the Necessary God: Trinitarian Faith and Philosophy in the Thought of Eberhard Jüngel (Atlanta, GA: Scholars Press, 1999). For Webster's later comments on simplicity, see: 'Divine Attributes', pp. 47-8; 'Non ex aequo: God's Relation to Creation', in GWM, vol. 1, pp. 120, 125-6.

${ }^{42}$ Webster, 'Trinity and Creation', p. 91; quoting David Braine, The Reality of Time and the Existence of God (Oxford: Clarendon Press, 1988), p. 348.
} 
of the Father, Son and Spirit as intrinsic to the modus perfectionis of God's life. Since the relations denominated by 'generation' and 'spiration' are uncreated, they are possessed of the eternality, impassibility and stability of God's simple beatitude. These relations therefore help us grasp Jesus' words, 'I and the Father are one' (John 10:30). The Son's unity with the Father is ontological, and not merely moral or vocational, somehow established by Jesus' active consent to his office. Rather is the Son's place in the perfection of God itself necessary and something without which we find unintelligible both theology and economy. Indeed, without the recognition of the Son's eternal generation, we cease to understand the economy as an economy, and instead see it as groundless 'temporal surface'. Tellingly, the more we lose a sense of the economy as 'an ordered exhibition of the works of God', the more we lose a sense of our place in a history determined at every point by the God who gives us our nature and its vocation. ${ }^{43}$ Thus it is that what Barth called 'untheological speculation' inhibits our understanding of grace, the moral life it quickens and much else besides. ${ }^{44}$

\section{5}

Though the distinction between theology and economy is a crucial element of the doctrine of God and the kind of inquiry that is fittingly attuned to it, it cannot remain alone. This is why the distinction between theology and economy is 'not a separation'. ${ }^{4}$ To hold together God's perfection and presence coherently, we must acknowledge 'the continuous identity of the acting subject in God's inner and outer works' ${ }^{46}$ Conceptual articulation of this continuous identity distinguishes without separating theology and economy, and for Webster it does so through an understanding of God's goodness and love. What links together God's inner and outer works is that God is love, both within and without his perfect life: 'The love of God ... has its term primarily in itself but secondarily in the existence of what is other than God. ${ }^{47}$

\section{1}

Though Webster relies on God's holiness in his earlier work to ground the distinction and relationship between God's inner being and outer works, this emphasis disappears in his mature thought. It is not that holiness is unimportant or somehow no longer a central element of his thinking, but it does cease to bear the burden of displaying the continuous identity of God in his inner and outer works. Instead, Webster finds in the patristic, medieval, Reformation and post-Reformation traditions a concept of God's goodness that serves this purpose to greater effect. God's goodness is a moral because ontological concept, referring us to God's entirely realised nature in himself, and on this basis to the economy of his works befitting this absolute perfection. ${ }^{48}$ Goodness thus knits together perfection and presence, theology and economy.

\footnotetext{
${ }^{43}$ Webster, 'Eternal Generation', p. 40. On the significance of 'history' in Webster's thought, see Martin Westerholm, 'On Webster's God without Measure and the Practice of Theological Theology', International Journal of Systematic Theology 19/4 (2017), pp. 444-61.

${ }^{44}$ See Karl Barth, Church Dogmatics, I/1, ed. G. W. Bromiley and T. F. Torrance, trans. G. W. Bromiley, G. T. Thomson and Harold Knight (London: T\&T Clark, 2009), pp. 420-1. Webster argues that distinctions like these are soteriologically necessary: 'Soteriology and the Doctrine of God', pp. 143-57.

${ }^{45}$ Webster, 'Christology, Theology, Economy', p. 46.

${ }^{46}$ Webster, 'On the Matter of Christian Theology', p. 8.

${ }^{47}$ Webster, 'Trinity and Creation', p. 93; Webster, 'Love Is Also a Lover of Life: Creatio ex nihilo and Creaturely Goodness', in GMW, vol. 1, p. 110.

${ }^{48}$ Webster, 'Love Is Also a Lover of Life', p. 104.
} 
As concerns God's intrinsic life, goodness is identical with God's being and therefore pure act. ${ }^{49}$ God's goodness is beyond supplement, already possessed in the perfect love characterising his triune life: 'God is in himself replete, unoriginated love, the reciprocal fellowship and delight of the three and the utter repose and satisfaction of their love'. ${ }^{50}$ In this light, love is goodness in communication, and it shows that God's goodness considered absolutely is that in which God rests actively and thus without detriment to his livingness.

Since God is love and his goodness is eternally communicative, then 'to God's absolute, intrinsic goodness there corresponds his relative, extrinsic goodness, that is, the divine benignity whose ground is the inner divine bonitas. ${ }^{51}$ Webster here adopts some standard scholastic distinctions to secure the intrinsic connection between God's goodness in se and his goodness pro nobis, without confusing them. God's benignity is 'the principle of God's disposing of himself towards creatures, bestowing, conserving and perfecting creaturely life'. In this sense, benignity signals the readiness or tendency of God's goodness to communicate itself externally. ${ }^{52}$ Its full scope is captured by surveying its twofold character: first God's benignity is his benevolence or 'decretive goodness, his unshakeable determination to be and act for the creature'; second, God's benignity is his beneficence or 'executive goodness, his enactment of the creaturely good which he wills'. Webster sums this up: 'God's active benevolence is the effect of his willed goodness, resting upon his benignity; and this benignity is the outer, communicative face of his goodness in himself. ${ }^{53}$ Such distinctions have the benefit of showing how God's absolute goodness in himself, eternally communicated in the love that defines the fellowship between the Trinity, grounds and finds fitting expression in the economy of God's communicative presence to creatures.

\section{3}

These distinctions concerning God's goodness and love reinforce theology's contemplative end and therefore the exegetical means towards this end. God's goodness has an absolute character rooted in the perfect fellowship of the Father, Son and Spirit, and which also takes on an economic form that it otherwise would not have. ${ }^{54}$ In an earlier writing, Webster voices some reservations about 'an excessively neat distinction' between the matter and the mode of revelation in traditional accounts of divine accommodation and condescension. ${ }^{55}$ Without explicitly retracting this concern, the

\footnotetext{
${ }^{49}$ Webster, 'Mercy', in GMW, vol. 2, p. 54.

${ }^{50}$ Webster, 'Trinity and Creation', p. 92.

${ }^{51}$ Webster, 'Mercy', p. 54.

${ }^{52}$ Though space prohibits us from examining it, there are hints that Webster endorses the notion of goodness as self-communicative (bonum communicativum sui est). For instance, see Webster, 'Theology and the Order of Love', in Markus Mühling et al. (eds), Rationalität im Gespräch: Philosophische und Theologische Perspektiven (Leipzig: Evangelische Verlagsanstalt, 2016), pp. 175-6; 'Love Is Also a Lover of Life', p. 112. Because the Trinity is love in se, then the communication finds its necessary term ad intra and its contingent term ad extra.

${ }^{53}$ Ibid.; 'On the Matter of Christian Theology', p. 10; “A Relation beyond All Relations”: God and Creatures in Barth's Lectures on Ephesians, 1921-22', in Karl Barth, The Epistle to the Ephesians, trans. Ross M. Wright (Grand Rapids, MI: Baker Academic, 2017), p. 49. Elsewhere, Webster characterises God's active benevolence in terms of the Reformed doctrine of the pactum salutis ("In the Society of God": Some Principles of Ecclesiology', in GMW, vol. 1, p. 183).

${ }^{54}$ Webster, 'Perfection and Participation', p. 381.

${ }^{55}$ John Webster, Holy Scripture: A Dogmatic Sketch (Cambridge: Cambridge University Press, 2003), p. 22.
} 
contemplative ramifications of God's goodness mean that 'the matter of revelation (revelata) is not simply identical with the form or medium of revelation (modus revelationis)'. ${ }^{56}$ Therefore, when God's goodness is referred to God's will ad extra as benevolence, it 'takes the beneficent form of mercy in the situation of creaturely distress'; ${ }^{57}$ and 'in the wake of Adam's defection, takes redemptive form' ${ }^{58}$ This distinction of res and form means the irreversibility and asymmetry between God's perfection and God's presence. ${ }^{59}$ God is self-consistently God in his inner and outer works, but divine goodness gives the latter a ground and end higher than themselves. The conceptual refinements of God's goodness enable us to register the delicate though vital thought that the content and form of revelation are not identical in every respect.

6

All of the preceding leads to and depends materially upon the viability of the thought of God in relation to God. This does two things. First, it colours our understanding of how perfection and presence are knit together. Second, perceiving that God's intrinsic perfection includes necessarily a moment of utter self-referentiality leads to the insight that God's relation to creation is non-adventitious. To secure this point 'entails bringing together a formal conception of infinity as non-composite, utterly underivative "difference" and a materially dense theology of the Trinity's perfect beatitude, using the former to explicate how the latter relates in a "non-real" way to what is not itself. 60 Unpacking each of these aspects will help us to see the full consequences of a theological theology proper.

\section{1}

To begin with, the concept of infinity is formal rather than material. Earlier we saw Webster's conviction that descriptively adequate concepts are materially precise and transparent to what they summarise in scripture. Concepts that are overly formal leave too much unsaid, but the opposite danger is also real, namely, that some concepts can be too material. The concept of God's infinitude is a case in point. For instance, Hegel's account of the 'true infinite' (wahrhaft Unendliche) includes the finite as sublated within itself, and therefore portrays something coming to itself in this process. ${ }^{61}$ Webster's unease with such an account of infinitude is that it fails to register the full asymmetrical difference of God's relation to creation, and so threatens to collapse theology and economy. It also says far too much. Infinitude simply recalls that God is 'inscrutable' (Rom 11:33) and that God's greatness is 'unsearchable' (Ps 145:3). God is unbound, incommensurate with everything, eternally living and immense: without measure. Who it is that is 'without measure' is something we don't learn from the concept of infinitude itself.

\footnotetext{
${ }^{56}$ Webster, 'On the Matter of Christian Theology', p. 6.

${ }^{57}$ Webster, 'Love is Also a Lover of Life', p. 104.

${ }^{58}$ Webster, "On the Matter of Christian Theology', p. 10.

${ }^{59}$ Contrast this with his earlier coordination of God's inner and outer works as almost reciprocally determined: 'The Immensity and Ubiquity of God', in Confessing God, p. 87.

${ }^{60}$ Webster, 'Trinity and Creation', p. 91.

${ }^{61}$ Georg W. F. Hegel, The Science of Logic, trans. George di Giovanni (Cambridge: Cambridge University Press, 2010), pp. 108-25; Robert R. Williams, 'Hegel's Concept of the True Infinite', Owl of Minerva 42/1 (2010), pp. 89-122; cf. Webster's critique of Wolfhart Pannenberg in this connection in Holiness, p. 109, n. 25 .
} 


\section{2}

The material duties are rather found in divine beatitude, God's fullness of riches in himself that relieves all his external works 'from having to supply the creator's poverty'. ${ }^{62}$ God is the fullness of his own life, and so rests in himself. This beatitude encompasses the peace of God's life: 'In the loving circle of paternity, filiation and spiration, there is no malign diversity, no coming together out of a condition of separation, no overcoming of division or conflict, but always an already-achieved perfection of peaceful life. ${ }^{63}$ Because God is in himself perfectly happy and at rest, his work of creation is an act of generosity in which he gives but does not receive. It does ground a genuine giving: 'God's infinite beatitude includes infinite love extended outwards; it is an inner bliss which is causal, limitlessly generous, that by virtue of which created history comes to be. ${ }^{\prime 64}$ But precisely because God's generosity issues from his beatitude, his relation to creation is 'non-real'. Far from denying any relation, this (austere) concept describes the relations God bears towards all that is not God. It is another way of saying that God relates to things without any benefit to God and thus without scheming for what God might get out of the arrangement. ${ }^{65}$ The relation is one of miraculous gratuity all the way down.

\section{3}

The consequence of these formal and material concepts when juxtaposed is an account of God's perfection that enables us to register the thought of God in relation to God, where the notion of solus Deus comes into its own. Such perception adheres to the 'rule that the Holy Trinity is perfect blessedness in himself in the absence of creatures' ${ }^{66}$ To state the point bluntly: "In the perfection of his immanent triune life, God "only" is God, and God is "alone". 67 That is, God's perfection in himself registers the distinction between God and creatures 'beyond both reciprocity and dialectic ... the triune God could be without the world; no perfection of God would be lost, no triune bliss compromised, were the world not to exist; no enhancement of God is achieved by the world's existence'. ${ }^{68}$ When set forth in this manner, God's perfection is not an 'inclusive', but 'exclusive' perfection in that it does not have creatures as an integral aspect of the fullness it describes. ${ }^{69}$ Simply in view of what God's perfection is, then, it cannot be extended such that God might even freely bring about a 'state of affairs in which God's fullness now includes his relation to creatures'. ${ }^{70}$ By virtue of God's perfection, God has nothing to gain and everything to give. So theology may confidently set aside the dichotomy of God's glory or our own (aut gloria Dei aut gloria hominis). It is precisely the 'exclusive' character of God's glory, one which neither opposes nor synthesises with creation, that ensures the creature's good and its dignity: 'only when we have come to

\footnotetext{
${ }^{62}$ Webster, 'Trinity and Creation', p. 93.

${ }^{63}$ Webster, 'Theology and the Peace of the Church', in DW, p. 154.

${ }^{64}$ Webster, 'Christology, Theology, Economy', p. 47

${ }^{65}$ Webster, 'Love Is Also a Lover of Life', p. 107.

${ }^{66}$ Webster, 'Trinity and Creation', p. 89; 'Christology, Theology, Economy', p. 46.

${ }^{67}$ Webster, 'Non ex aequo', p. 121.

${ }^{68}$ Webster, 'Trinity and Creation', p. 91.

${ }^{69}$ John Webster, 'On Evangelical Ecclesiology', in Confessing God, p. 158; 'Non ex aequo', p. 121.

${ }^{70} J o h n$ Webster, 'Creation Out of Nothing', in Michael Allen and Scott R. Swain (eds), Christian

Dogmatics: Reformed Theology for the Church Catholic (Grand Rapids, MI: Baker Academic, 2016), p. 138.
} 
know that God is beyond all relations may we understand and enact the relation to him in which we have been caused to stand'. ${ }^{71}$

\section{Conclusion}

What does the foregoing sketch suggest about a theological theology proper? Formally, we may conclude that whatever one says about God's perfection will stand in a mutually implicating mode of inquiry, along with the habits, rhetoric and forms of criticism conducive to it. Neglect of this feature is pervasive in many of the debates over God's perfection among philosophers of religion, where methods of inquiry are often settled in advance of considering the form of God's objective self-presentation. But the danger can be just as alive and well in more explicitly dogmatic contexts, where commitments to certain metaphysical tools or modes of argumentation may be assumed rather than justified. Regardless of the contexts in which it may apply, Webster is surely correct when he warns that the theological concept of God's perfection needs 'a thorough contemporary treatment, and the lack of such a treatment is not often acknowledged' ${ }^{72}$ Substantively we have seen that for Webster, an 'an evangelically-determined theology of God's perfection' requires a materially dense account of the Trinity's blessed life that registers the thought of God in relation to God as it is prompted by the form of God's self-revelation. Moreover, such an account will only be truly determined by the evangel if it does equal justice to God's fellowship with creatures in the covenant. Even though we distinguish them, God's perfection and God's presence must be knit together if we are to attest the gospel's God.

However, there are serious questions that this portrait must face. For some critics, the Thomist definition of theology's object does not transparently take humanity and its sinfulness with sufficient seriousness. ${ }^{73}$ Luther famously comments that it is useless for someone 'to recognize God in Divine glory and majesty, unless one recognizes God in the humility and shame of the cross'. ${ }^{74}$ Perhaps a theological theology proper prompts us to recognise how this insight cuts both ways: it is useless to recognise God in the humility of the cross unless we also recognise God in his beatitude. Without the latter, the former loses its power just as much as without the former, the latter loses its material specificity. More significantly, some wonder how such a focus on God's inner life is viable after Kant, and whether the proportions Webster attributes to God's inner life reflect the emphases of scripture. ${ }^{75}$ Indeed, Webster does not give enough attention to showing exegetically how it is that this account of God's perfect life corresponds to the form of God's self-expression. ${ }^{76}$ Perhaps this is a by-product of the occasional nature of his literary output, and would have been resolved in his unwritten Systematic Theology. And Webster's comments on the nature of theological reason suggest that the 'post-Kantian' setting is not necessarily the barrier

\footnotetext{
${ }^{71}$ Webster, 'A Relation beyond All Relations', p. 49; 'Love Is Also a Lover of Life', pp. 110-11.

${ }^{72}$ Webster, Confessing God, p. 3.

${ }^{73}$ Willem Maarten Dekker, 'John Webster's Retrieval of Classical Theology', Journal of Reformed Theology 12/1 (2018), pp. 59-63.

${ }^{74}$ Martin Luther, Heidelberg Disputation, \$20, in Martin Luther’s Basic Theological Writings, ed. William R. Russell and Timothy F. Lull, 3rd edn (Minneapolis, MN: Fortress, 2012), p. 22.

${ }^{75}$ For these and other friendly criticisms, see Tom Greggs, 'The Call to Focus on God: A Review of Webster's God without Measure', Modern Theology 34/4 (2018), pp. 657-63.

${ }^{76}$ For some hints of Webster's thinking in this regard, see 'Response to George Hunsinger', Modern Theology 8/2 (1992), pp. 129-32.
} 
to the kinds of reflection he enjoins that many think it is. But it does deserve more treatment than he afforded it. Whatever the case may be, the account of God's perfection that Webster challenges theologians to develop will have to answer these critical questions in greater depth. Even so, Webster is instructive not only for laying bare key elements of a theological theologia, but also for modelling its joyful pursuit.

Cite this article: Wittman T (2020). John Webster on the task of a properly theological theologia. Scottish Journal of Theology 73, 97-111. https://doi.org/10.1017/S003693062000023X 